\title{
Extraction of fibrinolytic proteases from Streptomyces sp. DPUA1576 using PEG-phosphate aqueous two-phase systems
}

\author{
Germana Michelle de Medeiros e Silva ${ }^{a}$, Daniela de Araújo Viana Marques ${ }^{\mathrm{b}}$, Tatiana Souza Porto ${ }^{\mathrm{b}, \mathrm{c}}$, \\ José Luiz Lima Filho a, José António Couto Teixeira ${ }^{\mathrm{d}}$, Adalberto Pessoa-Júnior ${ }^{\mathrm{e}}$, \\ Ana Lúcia Figueiredo Porto ${ }^{\mathrm{a}, \mathrm{b}, *}$ \\ a Laboratory of Immunopathology Keizo Asami (LIKA), Universidade Federal de Pernambuco-UFPE, Av. Prof. Moraes s/n, 50670-901 Recife, PE, Brazil \\ ${ }^{\mathrm{b}}$ Department of Morphology and Animal Physiology, Universidade Federal Rural de Pernambuco-UFRPE, Av. Dom Manoel de Medeiros s/n, 52171-900 Recife, PE, Brazil \\ ${ }^{\mathrm{c}}$ Academic Unit of Garanhuns/UFRPE, Avenida Bom Pastor, s/n, Boa Vista - CEP: 55292-270, Garanhuns, PE, Brazil \\ ${ }^{\mathrm{d}}$ Institute for Biotechnology and Bioengineering, Centre of Biological Engineering, Universidade do Minho, Campus de Gualtar, 4710-057 Braga, Portugal \\ e Department of Biochemical and Pharmaceutical Technology, University of São Paulo, Av. Prof. Lineu Prestes, 580, Bloco 16, Cidade Universitária, 05508-000 São Paulo, SP, Brazil
}

\section{A R T I C L E I N F O}

\section{Article history:}

Received 9 August 2012

Received in revised form

19 November 2012

Accepted 20 November 2012

Available online 29 November 2012

\section{Keywords:}

Aqueous two phase system

Fibrinolytic protease

Partition

PEG/phosphate

Extraction

\begin{abstract}
A B S T R A C T
Extraction of fibrinolytic protease from Streptomyces sp. DPUA1576 fermentation broth was performed using polyethylene glycol (PEG) - phosphate salts aqueous two phase system (ATPS). The influence of $\mathrm{pH}$, PEG molar mass, PEG and phosphate concentrations on fibrinolytic protease partition coefficient $(K)$ were evaluated by $2^{4}$ full factorial design. Fibrinolytic protease partitioned preferentially to the (PEG)rich phase with the highest partition coefficient $(K=37.00)$ obtained in the system $20 \%(w / w)$ PEG 1500 $(\mathrm{g} / \mathrm{mol})-14 \%(\mathrm{w} / \mathrm{w})$ phosphate at $\mathrm{pH}$ 8.0. The system that allowed for the highest extraction consisted of $15 \%(\mathrm{w} / \mathrm{w})$ PEG $3350-12 \%(\mathrm{w} / \mathrm{w})$ phosphate, at $\mathrm{pH}$ 7.0. In these conditions, a purification factor of 1.51 was obtained for a partition coefficient of 6.41 with the fibrinolytic activity (FA) retained in the top phase. Obtained results confirm the interest of considering ATPS as an alternative extraction method for fibrinolytic protease from Streptomyces sp. DPUA1576.
\end{abstract}

(c) 2012 Elsevier B.V. All rights reserved.

\section{Introduction}

Fibrinolytic proteases are agents that hydrolyze fibrin, a major component of thrombus. These enzymes have been found in dung beetles [1], worms [2,3] and snakes [4,5]. However, microbial sources have been attracting a high medical interest during last decades [6-9].

Fibrin is formed by the conversion of molecular soluble fibrinogen into fibrin monomers that polymerize spontaneously and create a fibrin gel network. Fibrin not only provides strength and structure to the clot, but regulates the rate of its own formation and destruction [10,11]. Accumulation of fibrin in blood vessels usually increases thrombosis, leading to myocardial infarction and other cardiovascular diseases. The typical thrombolytic agents for therapeutic purposes include urokinase and a tissue-type plasminogen activator (t-PA) [12]. However, these agents have some

\footnotetext{
* Corresponding author at: Laboratory of Immunopathology Keizo Asami (LIKA), Universidade Federal de Pernambuco-UFPE, Av. Prof. Moraes s/n, 50670-901 Recife, PE, Brazil. Tel.: +55 8133206345 .

E-mail address: analuporto@yahoo.com.br (A.L.F. Porto).
}

disadvantages as high cost and internal bleeding within intestinal tract when orally administrated. Microbial sources emerge as an alternative for thrombolytic therapy [13] and are important sources of fibrinolytic agents. Streptokinase produced by Streptococcus hemolyticus and staphylokinase produced by Staphylococcus aureus proved to be effective for thrombolytic therapy [14,15].

The cost of enzyme production and downstream processing is the major obstacle against the successful application of fibrinolytic protease in industry [16]. There is a high demand for efficient and low cost extraction and purification methods, being aqueous two phase system (ATPS) an alternative that should be considered. ATPS have been used efficiently in the early stages of the purification process, but in some cases can even replace the traditional chromatographic systems [17].

Polymer-salts ATPS have been used for the partitioning and yield of various proteases and hence provide some advantages including low cost, rapid phase splitting, and low viscosity when compared to polymer-polymer systems $[18,19]$.

In this work, the influence of parameters such as $\mathrm{pH}$, PEG molar mass, PEG and phosphate salts concentrations on the partition and extraction of fibrinolytic protease from Streptomyces sp. DPUA1576 is evaluated. 
Table 1

Salts components concentration at different $\mathrm{pH}$ values of the ATPS.

\begin{tabular}{llll}
\hline Salts (\%) & $\mathrm{pH}$ & & \\
\cline { 2 - 4 } & 6 & 7 & 8 \\
\hline Monobasic sodium phosphate & 53.1 & 29.9 & 11.4 \\
Dibasic potassium phosphate & 46.9 & 70.1 & 88.6 \\
\hline
\end{tabular}

\section{Materials and methods}

\subsection{Reagents}

Polyethylene glycol (PEG) with molar mass of 400, 3350, 8000 $(\mathrm{g} / \mathrm{mol})$ and monobasic sodium phosphate $\left(\mathrm{NaH}_{2} \mathrm{PO}_{4}\right)$ and dibasic potassium phosphate $\left(\mathrm{K}_{2} \mathrm{HPO}_{4}\right)$ salts were obtained from Sigma (St. Louis, MO, USA). All other chemical reagents were of analytical grade.

\subsection{Microorganism}

The Streptomyces sp. (DPUA1576) strain was obtained from Culture Collection of Parasitology Department of the Federal University of Amazonas (DPUA-Brazil). Stock culture was maintained at $25^{\circ} \mathrm{C}$ in Castellani method [20].

\subsection{Media and culture condition}

The medium used for fibrinolytic protease production was the soybean flour medium described by Porto et al. [21]. Strains were cultured on ISP-2 [22] agar plates and incubated for seven days at $30^{\circ} \mathrm{C}$. The cultured strain was further inoculated in ISP-2 medium for $48 \mathrm{~h}$ at $28^{\circ} \mathrm{C}$. Thereafter, a cellular suspension of $10^{6}$ spores $/ \mathrm{mL}$ was inoculated in $250 \mathrm{~mL}$ Erlenmeyer flask containing $50 \mathrm{~mL}$ of soybean flour medium. The crude extract (clarified by centrifugation at $8000 \times \mathrm{g}$ at $4{ }^{\circ} \mathrm{C}$ for $10 \mathrm{~min}$ ) was submitted to FA determination after $72 \mathrm{~h}$ of cultivation.

\subsection{Preparation of the aqueous two phase systems}

Aqueous two phase systems (ATPS) were prepared in $15 \mathrm{~mL}$ graduated tubes with $40 \%(\mathrm{w} / \mathrm{w})$ of phosphate salts mixture solutions and 50\% (w/w) PEG solutions at different $\mathrm{pH}$ values (6.0, 7.0, $8.0)$ at $25 \pm 1\left({ }^{\circ} \mathrm{C}\right)$ according to statistical design described in item 2.7. Monobasic sodium phosphate and dibasic potassium phosphate were used in different concentrations allowing obtaining the different $\mathrm{pH}$ values of the ATPS, according Table $1 . \mathrm{K}_{2} \mathrm{HPO}_{4}$ and $\mathrm{NaH}_{2} \mathrm{PO}_{4}$ display greater solubility than their respective monobasic and dibasic salts [23]. The amount of $2 \mathrm{~g}$ dissolved fibrinolytic protease $(187 \mathrm{mg} / \mathrm{mL})$ and water was added to a final amount of $10 \mathrm{~g}$. After addition of all components of the system (PEG solution + phosphate salts solution + water + fermented broth culture medium) and vortex shaking for $1.0 \mathrm{~min}$, the two phases were separated by settling for $60 \mathrm{~min}$. The $\mathrm{pH}$ of all system was measured and there was no significant change $( \pm 0.2)$ using Micronal $\mathrm{pH}$ meter, reference $\mathrm{B} 474$. Then, the top and bottom phases were separately and assayed for protein concentration and FA [24].

\subsection{Enzyme assay}

FA was determined according to the method described by Wang et al. [25]. In this assay, one unit (fibrin degradation unit, U) of enzyme activity is defined as a 0.01 -per-min increase in absorbance at $275 \mathrm{~nm}$ of the reaction solution. All experiments were performed in duplicate.
Table 2

Experimental design $2^{4}$ for fibrinolytic protease partition using PEG-phospate ATPS.

\begin{tabular}{lccc}
\hline Variables & \multicolumn{3}{l}{ Levels } \\
\cline { 2 - 4 } & Low $(-1)$ & Central $(0)$ & High $(+1)$ \\
\hline $\mathrm{pH}$ & 6.0 & 7.0 & 8.0 \\
${ }^{\mathrm{a}} \mathrm{M}_{\mathrm{PEG}}(\mathrm{g} / \mathrm{mol})$ & 1500 & 3350 & 8000 \\
${ }^{\mathrm{b}} \mathrm{C}_{\mathrm{PEG}}(\%, \mathrm{w} / \mathrm{w})$ & 10 & 15 & 20 \\
${ }^{\mathrm{c}} \mathrm{C}_{\mathrm{PHO}}(\%, \mathrm{w} / \mathrm{w})$ & 10 & 12 & 14 \\
\hline
\end{tabular}

a PEG molar mass.

b PEG concentration.

c Phosphate concentration.

\subsection{Protein determination}

Determination of total protein content was carried out by the Bradford method using bovine serum albumin as standard [26].

\subsection{Experimental design}

For statistical elaboration, the actual values of the independent variables $\left(X_{i}\right)$ were coded according to the equation:

$x_{i}=\frac{X_{i}-X_{0}}{\Delta X_{i}}$

where $x_{i}$ represents the corresponding coded values, $X_{0}$ the actual values at the central point, and $\Delta X_{i}$ the step change value.

A $2^{4}$ full factorial design was utilized to evaluate the influence of the four independent variables, namely $\mathrm{pH}\left(x_{1}\right)$, PEG molar mass $\left(x_{2}\right)$, PEG concentration $\left(x_{3}\right)$ and phosphate salt concentration $\left(x_{4}\right)$ on the selected response $K$, in this case the partition coefficient of the FA [27]. The experimental design was composed of 16 runs and 4 repetitions at the central point, needed to calculate the pure error (Table 2). The goodness of fit was evaluated by the coefficient of determination $\left(R^{2}\right)$ and the analysis of variance (ANOVA); the firstorder equation was determined by Fischer's test. The experimental and predicted values were compared and validated with Statistica $8.0[28]$.

\subsection{Determination of partition coefficient, yield and purification factor}

The partition coefficient, $K$ (dimensionless parameter) in the aqueous two-phase system was defined as the ratio of $\mathrm{FA}(\mathrm{U} / \mathrm{mL})$ in the top phase $\left(\mathrm{FA}_{t}\right)$ to that in the bottom phase $\left(\mathrm{FA}_{b}\right)$ (Eq. (2))

$K=\frac{\mathrm{FA}_{t}}{\mathrm{FA}_{b}}$

The purification factor $(P$, dimensionless parameter) was calculated as the ratio of the specific activity of fibrinolytic protease in the top phase and initial specific activity of crude extract. Specific activity $(\mathrm{U} / \mathrm{mg}$ ) is given by the ratio between volumetric activity $(\mathrm{U} / \mathrm{mL})$ and protein concentration $(\mathrm{mg} / \mathrm{mL})$. (Eq. (3))

$P=\frac{\mathrm{FA}_{t} / C_{t}}{\mathrm{FA}_{i} / C_{i}}$

$\mathrm{FA}_{i}$ is fibrinolytic activity in the initial crude extract, $C_{t}$ and $C_{i}$ are total protein concentrations, expressed as $\mathrm{mg} / \mathrm{mL}$, in the top phase and crude extract, respectively.

The yield ( $\mathrm{Y} \%$ ) was determined as the ratio of FA $\left(\mathrm{FA}_{t}\right)(\mathrm{U} / \mathrm{mL})$ in the top phase and in the crude extract $\left(\mathrm{FA}_{i}\right)(\mathrm{U} / \mathrm{mL})$ expressed as percentage (Eq. (4))

$Y=\left(\frac{\mathrm{FA}_{t} \cdot V_{\mathrm{t}}}{\mathrm{FA}_{i} \cdot V_{i}}\right) \cdot 100$

where $V_{t}(\mathrm{~mL})$ and $V_{i}(\mathrm{~mL})$ are the volumes of the top phase and the crude extract, respectively. 
Table 3

Matrix of the full factorial design $\left(2^{4}\right)$ with conditions and results of the fibrinolytic protease partition.

\begin{tabular}{|c|c|c|c|c|c|c|c|c|c|}
\hline Run & $\mathrm{pH}$ & $\mathrm{M}_{\mathrm{PEG}}{ }^{\mathrm{a}}(\mathrm{g} / \mathrm{mol})$ & $\mathrm{C}_{\mathrm{PEG}}^{\mathrm{b}}(\%)$ & $\mathrm{C}_{\mathrm{PHO}}{ }^{\mathrm{c}}(\%)$ & $\mathrm{K}^{\mathrm{d}}$ & $Y^{\mathrm{e}}(\%)$ & $P^{\mathrm{f}}$ & $\mathrm{FA}^{\mathrm{g}}(\mathrm{U} / \mathrm{mL})$ & $S d^{h}$ \\
\hline $1^{\mathrm{i}}$ & 6.0 & 1500 & 10 & 10 & - & - & - & 0.00 & 0.00 \\
\hline $2^{\mathrm{i}}$ & 8.0 & 1500 & 10 & 10 & - & - & - & 0.00 & 0.00 \\
\hline 3 & 6.0 & 8000 & 10 & 10 & 1.63 & 50 & 1.00 & 45.56 & 6.93 \\
\hline 4 & 8.0 & 8000 & 10 & 10 & 0.91 & 20 & 0.25 & 18.15 & 0.64 \\
\hline 5 & 6.0 & 1500 & 20 & 10 & 7.02 & 123 & 1.02 & 56.57 & 0.07 \\
\hline 6 & 8.0 & 1500 & 20 & 10 & 5.64 & 68 & 0.61 & 37.08 & 0.21 \\
\hline 7 & 6.0 & 8000 & 20 & 10 & 3.30 & 149 & 1.09 & 63.33 & 0.42 \\
\hline 8 & 8.0 & 8000 & 20 & 10 & 0.94 & 34 & 0.27 & 20.65 & 1.98 \\
\hline $9^{\mathrm{i}}$ & 6.0 & 1500 & 10 & 14 & - & - & - & 0.00 & 0.00 \\
\hline 10 & 8.0 & 1500 & 10 & 14 & 8.08 & 56 & 0.60 & 61.76 & 1.41 \\
\hline 11 & 6.0 & 8000 & 10 & 14 & 2.61 & 43 & 0.56 & 43.98 & 1.56 \\
\hline 12 & 8.0 & 8000 & 10 & 14 & 1.51 & 21 & 0.27 & 24.81 & 0.64 \\
\hline 13 & 6.0 & 1500 & 20 & 14 & 21.00 & 69 & 0.26 & 23.33 & 0.64 \\
\hline 14 & 8.0 & 1500 & 20 & 14 & 37.00 & 69 & 0.58 & 47.96 & 1.06 \\
\hline 15 & 6.0 & 8000 & 20 & 14 & 0.72 & 14 & 0.07 & 6.11 & 0.71 \\
\hline 16 & 8.0 & 8000 & 20 & 14 & 4.28 & 46 & 0.34 & 33.70 & 0.42 \\
\hline 17 & 7.0 & 3350 & 15 & 12 & 6.41 & 155 & 1.51 & 108.06 & 0.64 \\
\hline 18 & 7.0 & 3350 & 15 & 12 & 4.43 & 148 & 1.51 & 107.87 & 0.64 \\
\hline 19 & 7.0 & 3350 & 15 & 12 & 3.41 & 117 & 1.12 & 81.76 & 1.98 \\
\hline 20 & 7.0 & 3350 & 15 & 12 & 3.51 & 116 & 1.06 & 81.02 & 0.21 \\
\hline
\end{tabular}

a PEG molar mass.

b PEG concentration.

c Phosphate concentration.

d Partition coefficient.

e Yield.

f Purification factor

g Fibrinolytic activity in the top phase.

h Standard deviation.

i No phase formation after addition of extract.

\section{Results and discussion}

\subsection{Effect of independents variables on the partition coefficient of fibrinolytic protease extraction using ATPS}

Experimental design results for partition coefficient $(K)$ of fibrinolytic protease extraction using ATPS PEG/phosphate are presented in Table 3. According to binodal curve obtained with PEG $1500 \mathrm{~g} / \mathrm{mol}$ [29], no phase separation was observed for runs (1, 2 and 9) as salt and PEG concentrations were below the curve. In conformity with the results presented in Table 3, in the majority of runs, fibrinolytic protease partition occurred preferentially on the top phase rich in PEG.

The influence of independent variables, pH, PEG molar mass $\left(\mathrm{M}_{\mathrm{PEG}}\right)$, PEG concentration $\left(\mathrm{C}_{\mathrm{PEG}}\right)$ and phosphate salt concentration $\left(\mathrm{C}_{\mathrm{PHO}}\right)$ on the protease partition coefficient is described by Table 4.

Table 4

Estimates effects of independent variables and their interactions on the partition coefficient $(K)$ of the fibrinolytic protease.

\begin{tabular}{lcc}
\hline Independent variable and interaction & Estimates effect & $p$ Value \\
\hline Mean/intercept & 5.62 & $<0.05$ \\
$x_{1}(\mathrm{pH})$ & 2.76 & $<0.05$ \\
$x_{2}\left(\mathrm{M}_{\mathrm{PEG}}\right)$ & -7.86 & $<0.05$ \\
$x_{3}\left(\mathrm{C}_{\mathrm{PEG}}\right)$ & 8.15 & $<0.05$ \\
$x_{4}\left(\mathrm{C}_{\mathrm{PHO}}\right)$ & 6.97 & $<0.05$ \\
$x_{1} x_{2}$ & -2.92 & $<0.05$ \\
$x_{1} x_{3} \mathrm{a}$ & 1.20 & 0.18 \\
$x_{1} x_{4}$ & 3.88 & $<0.05$ \\
$x_{2} x_{3}$ & -7.50 & $<0.05$ \\
$x_{2} x_{4}$ & -6.39 & $<0.05$ \\
$x_{3} x_{4}$ & 4.56 & $<0.05$ \\
\hline
\end{tabular}

$\mathrm{pH}\left(x_{1}\right)$.

PEG molar mass $\left(x_{2}\right)$.

PEG concentration $\left(x_{3}\right)$.

phosphate salt concentration $\left(x_{4}\right)$.

a Interaction estimate effect not statistically significant at 95\% confidence level.
All independents variables and their interactions were statistically significant at $95 \%$ confidence level except the interaction $\mathrm{pH}-\mathrm{C}_{\mathrm{PEG}}$ $\left(x_{1} x_{3}\right)$ and $p$-value was higher than 0.05 .

According to Table $4, \mathrm{pH}\left(x_{1}\right)$ increase has a positive effect in the partition coefficient, i.e., at alkaline $\mathrm{pH}$, protein partition preferentially to top PEG rich phase. The $\mathrm{pH}$ of the system influences the ionizable groups of a protein and alters the protein surface charges. At high $\mathrm{pH}$ values, the protein is more negatively charged than at low $\mathrm{pH}$, and therefore, the partition coefficient of the protein increases with increasing the $\mathrm{pH}[30]$, which may be due to the electrostatic interactions between the protein and the PEG units [31].

This is clearly shown as, a displacement in $\mathrm{pH}$ from 6.0 to 8.0 (runs 13 and 14) causes an increase in the partition coefficient. A similar result was observed by Babu et al. [32] as an increase from 3 to 9 in the partition coefficient of bromelain occurred when $\mathrm{pH}$ was increased from 6.0 to 9.0 using $18 \%$ of PEG 1500 and $14 \%$ of potassium phosphate ATPS.

On the report of Yang et al. [33] protein partition using ATPS is influenced by a number of parameters, such as $\mathrm{pH}$ system, type and concentration of salts present in the system, concentration and polymer molecular mass and protein properties (e.g. structure, hydrophobicity, molecular mass).

$\mathrm{C}_{\mathrm{PEG}}$ and $\mathrm{M}_{\mathrm{PEG}}$ positive ( $x_{2}$ and $x_{3}$ interaction) displayed positive and negative effects, respectively, indicating that the increase on $C_{P E G}$ and a decrease on $M_{P E G}$ causes an improvement on fibrinolytic protease partition to top PEG rich phase. In this work, the results obtained indicate that larger polymer size creates a repulsive effect on fibrinolytic protease partition, leading to a decrease in the coefficient partition (runs 10 and 12).

Myoglobin partition studies using PEG/poly(acrylic acid), with PEG with molecular mass from 4000 to $10,000 \mathrm{~g} / \mathrm{mol}$, demonstrated a decrease on $K$ from 15.77 to 4.33, whereas for ovalbumin the decrease was from 5.51 to 3.09 [29]. Low values for partition coefficient of bromelain were also observed by Ketnawa et al. [34] on PEG/MgSO 4 ATPS containing PEG with different molecular 


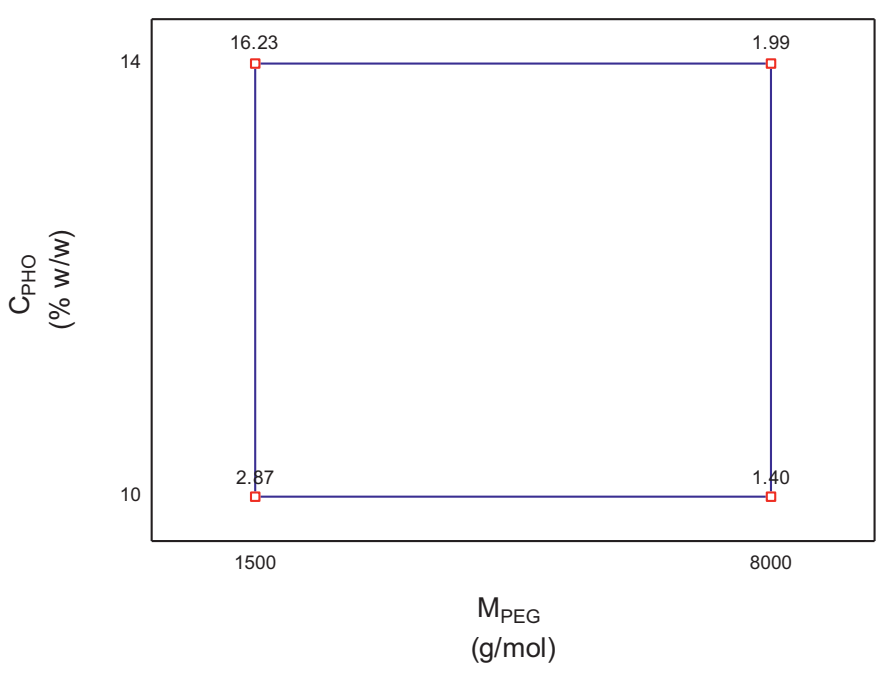

Fig. 1. Effects of the $C_{P E G}(\%)$ and $M_{P E G}(g / m o l)$ on the yield of fibrinolytic protease produced by Streptomyces sp. DPUA1576.

weights (2000-6000 g/mol). All these reported results corroborate our results where $K$ values ranged from 37.0 to 0.7 when $\mathrm{M}_{\mathrm{PEG}}$ increased from 1500 to $8000 \mathrm{~g} / \mathrm{mol}$.

The decrease in the partition coefficient of fibrinolytic protease may be associated with the increase of the hydrophobicity of the top phase coupled with the volume exclusion effect resulting from the use of higher PEG molar mass [35]. Babu et al. [32] indicate that there is a relation between the $\mathrm{M}_{\mathrm{PEG}}$ and partition coefficient $(K)$ as the increase on molar mass reduces the free space (excluded volume) available for biomolecules in the top phase leading to partition to the bottom phase.

It is also known that the presence of phosphate in aqueous two phase systems influences the partition of molecules by acting on the charge of proteins. The effect of salt on the partitioning coefficient of fibrinolytic protease was positive meaning that high phosphate concentration makes fibrinolytic protease migrate to the PEG rich phase. This can be explained by a salting out effect, where the biomolecule is directed to the other phase as a consequence of the great amount of salt in the bottom phase [33].

Phosphate ions can influence the protein partition by electrostatic interactions between biomolecules and the components of aqueous two phase system. With an increase in $\mathrm{C}_{\mathrm{PHO}}$, negatively charged proteins prefer the PEG-rich phase, because of the repulsion force caused by salt anions [35].

Rawdkuen et al. [36] studied the effect of salts on the partitioning of protease from Calotropis procera latex in ATPS using different salts $\left(\left(\mathrm{NH}_{4}\right)_{2} \mathrm{SO}_{4}, \mathrm{~K}_{2} \mathrm{HPO}_{4}\right.$, and $\left.\mathrm{MgSO}_{4}\right)$ at different concentrations $(14 \%(\mathrm{w} / \mathrm{w}), 17 \%(\mathrm{w} / \mathrm{w}), 20 \%(\mathrm{w} / \mathrm{w}))$. It was reported that the increase in concentration using $\left(\mathrm{NH}_{4}\right)_{2} \mathrm{SO}_{4}$ and $\mathrm{MgSO}_{4}$ showed an increase in protease partitioning to salt rich bottom phase. Meanwhile, the increase on $\mathrm{K}_{2} \mathrm{HPO}_{4}$ concentration caused an improvement on protease partition to PEG rich phase. This result showed a behavior similar to the one verified in our studies by increasing phosphate concentration from 10 to $14 \%$ (w/w) (runs 5 and 13).

$\mathrm{C}_{\mathrm{PHO}}$ and $\mathrm{M}_{\mathrm{PEG}}$ were the variables that most influenced the extraction process. Fig. 1 shows the effect of the interaction of these two variables in the protein partition coefficient. As demonstrated, a decrease of PEG molar mass from 8000 to $1500(\mathrm{~g} / \mathrm{mol})$ and an increase of $\mathrm{C}_{\mathrm{PHO}}$ from 10 to $14 \%$ improved the partition coefficient value from 0.79 to 37.00 , indicating the occurrence of simultaneous salting-out and exclusion volume effects.

The validity of the experimental design applied was verified by analysis of variance presented in Table 5 . For $K$ response, $F$ test was significant for all independent variables showing that this experimental design is adequate to describe the results, i.e., $F$ calculated (3.86) was higher than $F$-tabulated value (3.06). For determination coefficient- $R^{2}(0.90)$, a value close to 1 indicated agreement between the experimental and model predicted. The estimated effects and the corresponding $p$-values indicate that independent variables have a significant effect on the response studied $(p<0.05)$.

\subsection{Fibrinolytic protease partition, yield and purification factor}

Fibrinolytic protease partition using PEG/phosphate salts ATPS showed the highest yield value (155\%) (run 17 in Table 2 ) in the following conditions: $\mathrm{pH} 7.0, \mathrm{M}_{\mathrm{PEG}} 3350$ (g/mol), $\mathrm{C}_{\mathrm{PEG}} 15 \%(\mathrm{w} / \mathrm{w})$ and $\mathrm{C}_{\mathrm{PHO}} 12 \%(\mathrm{w} / \mathrm{w})$ for a total and specific fibrinolytic activity in the crude extract of $52.95 \mathrm{U} / \mathrm{mL}$ and $605.37 \mathrm{U} / \mathrm{mg}$, respectively.

Yields above and near $100 \%$ are frequently reported for enzyme extraction using aqueous two-phase systems. These results suggested that PEG is essentially an inert polymer that does not interact with protein, due its steric hydration properties [37]. However, several authors have found an interaction between PEG and protein, such as, for example, the dissociation are probably explained by the elimination of inhibitors during the purification process and by the composition of the systems, which PEG can influence enzyme active site and favors the enzymatic activity [38,39].

For PEG/citrate aqueous two phase system, Porto et al. [24] reported that the yield is improved with a decrease on $\mathrm{M}_{\mathrm{PEG}}$. They also reported an extraction yield of $255 \%$ for the extraction of proteases produced by Clostridium perfringens. Partial purification of lactate dehydrogenase and pyruvate from bovine heart crude extract by PEG-citrate systems was performed by Araújo et al. [40] and yields up to $163 \%$ in the top phase were obtained.

For phospholipase $C$ extraction, higher yield value is reached with $\mathrm{pH}$ alkalinization, decrease on $\mathrm{M}_{\mathrm{PEG}}, \mathrm{C}_{\mathrm{PEG}}$ and $\mathrm{C}_{\mathrm{PHO}}$ [41]. Neves et al. [42] obtained a yield of $115 \%$ using PEG with a molar mass of $8000 \mathrm{~g} / \mathrm{mol}$ and citrate concentration of $12 \%$ in the production of phytase by Absidia blakesleeana URM5604. In the case of the purification of lumbrokinase, a fibrinolytic enzyme from earthworm Eisenia fetida, using a PEG/phosphate system, Iannucci et al. [43] reported a yield of $99 \%$, and a purification factor of 1.0 , values that are lower than the ones obtained in our work.

The purification factor obtained in this study is also in agreement with other works in the literature reporting the purification of proteins from biological extracts, as is the case of bromelain $(P=1.81$, using PEG/phosphate system) [34], alkaline protease $(P=1.80$, using PEG/citrate system) [44] and xylose reductase $(P=1.1$ using PEG/phosphate system) [45].

The interaction between $\mathrm{C}_{\mathrm{PHO}}(\%)$ e $\mathrm{pH}$ on protease purification factor from Streptomyces sp. DPUA1576 fermentation broth by PEG/phosphate ATPS was observed in Fig. 2. The best results were obtained in central point runs ( $\mathrm{pH} 7.0, \mathrm{M}_{\mathrm{PEG}} 3350 \mathrm{~g} / \mathrm{mol}, \mathrm{C}_{\mathrm{PEG}}$ $15 \%(\mathrm{w} / \mathrm{w})$ and $\left.\mathrm{C}_{\mathrm{PHO}} 12 \%(\mathrm{w} / \mathrm{w})\right)$. As suggested that hidrogenionic forces did not favor the purification in the top phase where as major purification occurred in neutral $\mathrm{pH}$.

Yield and purification of fibrinolytic protease have been performed using high cost processes. Simkhada et al. [13] purified fibrinolytic protease from Streptomyces sp. CS684 by a three-step (ammonium sulfate fractionation, gel filtration and ion exchange chromatography) process resulting in a 10.5 -fold purification and $5.4 \%$ yield; Wang et al. [46] purified nattokinase from Bacillus subtilis in four steps (ammonium sulfate fractionation, gel filtration ion exchange and hydrophobic interaction chromatography) achieving an overall purification of 515 -fold and a $12 \%$ yield; a novel fibrinolytic protease was purified from Paenibacillus polymyxa EJS-3 using ammonium sulfate precipitation, gel filtration, hydrophobic and ion exchange chromatography, with a 14.5 purification factor and a $3.3 \%$ yield [47]. 
Table 5

Analysis of variance described for the response, $K$, over the independent variables according to $2^{4}$ full statistical design.

\begin{tabular}{|c|c|c|c|c|c|c|c|c|}
\hline Response & $\mathrm{df}$ & SS model & MS model & $F$-calc & $F$-tab & $R^{2}$ & $R_{\text {adjusted }}^{2}$ & $p$ Value \\
\hline \multicolumn{9}{|l|}{$K$} \\
\hline Regression & 4 & 736.96 & 184.24 & 3.86 & 3.06 & 0.90 & 0.79 & 0.024 \\
\hline Resid & 15 & 715.58 & 47.71 & & & & & \\
\hline Total & 19 & 1452.54 & - & & & & & \\
\hline
\end{tabular}

All values are statistically significant at 95\% confidence level. $\mathrm{df}=$ degree of freedom; $\mathrm{SS}$ model = model quadratic sum; MS model = model quadratic mean.

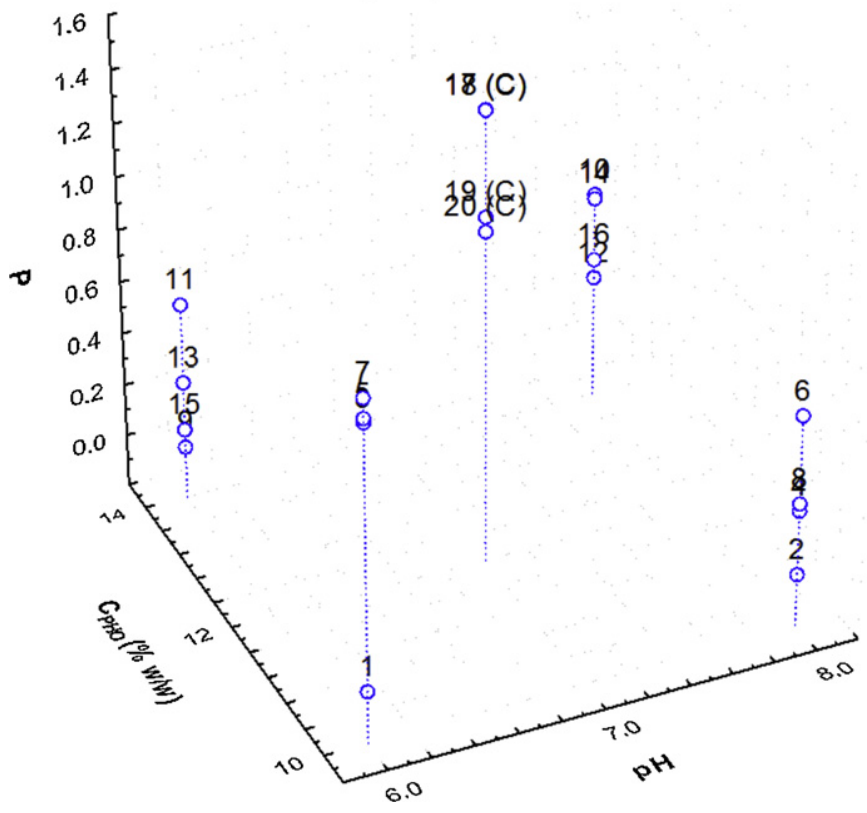

Fig. 2. Effects of $\mathrm{C}_{\mathrm{PHO}}(\%)$ e $\mathrm{pH}$ on purification of protease removal from Streptomyces sp. DPUA1576 fermentation broth by PEG/phosphate ATPS. Experiments performed according experimental design.

Therefore, our study using ATPS suggest a simple, rapid and reproducible low cost process for the yield and the purification of any enzyme. For example, the yield of the two proteins ( $\alpha$-lactalbumin and $\beta$-lactoglobulin) from cheese whey, using PEG/salt ATPS, allows a 50\% reduction in costs [48]. Several promising alternatives for purification of industrial enzymes, including precipitation, liquid-liquid extraction (e.g. aqueous two-phase extraction) and crystallization [49,50] have emerged to replace conventional methods like ammonium sulphate precipitation, chromatography, gel filtration and affinity chromatography or a combination of these techniques [51].

\section{Conclusion}

In this study, the extraction of fibrinolytic protease from a fermentation broth was evaluated being shown that it partitioned to the top phase of PEG-phosphate ATPS with $K \leq 37$. The variables that had the most important effect on the enzyme partition coefficient were PEG molar mass and phosphate salts concentration. The system that allowed for the highest extraction consisted of $15 \%(w / w)$ PEG 3350-12\% (w/w) phosphate, at $\mathrm{pH}$ 7.0. In these conditions, a purification factor of 1.51 was obtained for a partition coefficient of 6.41 with all the fibrinolytic activity retained in the top phase. Overall, it is demonstrated that ATPS are a potential alternative method for fibrinolytic protease extraction from the fermentation broth of Streptomyces sp. DPUA1576.

\section{References}

[1] M.Y. Ahn, B.S. Hahn, K.S. Ryu, J.W. Kim, Y.S. Kim, Thromb. Res. 112 (2003) 339-347.

[2] Z.R. Xu, Y.M. Yang, Q.F. Gui, L.N. Zhang, Protein Expr. Purif. 69 (2010) 198-203.

[3] M.B. Cheng, J.C. Wang, Y.W. Li, X.Y. Liu, X. Zhang, D.W. Chen, S.F. Zhou, Q. Zhang, J. Control. Release 129 (2008) 41-48.

[4] J.C. Perez, M.R. McKellerb, J.C. Pérezb, E.E. Sánchezb, M.S. Ramírezb, Toxicon 39 (2001) 621-632.

[5] T.T. Lorencetti, A.Z.P. Pereira, P.H. Lopes, E.R. Pereira, V. Kizltyka, L.F. Pereira, M.S. Elifio-Esposito, Estud. Biol. 27 (2005) 19-25.

[6] X. Zhang, Q. Liu, G. Zhang, H. Wang, Process Biochem. 45 (2010) 724-730.

[7] W. Wu, K. Hasumi, H. Peng, X. Hu, X. Wang, B. Bao., Mar. Drugs 7 (2009) 85-94.

[8] E. Yamamoto, S. Yamamichi, N.H. Choi-Miura, K. Hasumi, Thromb. Res. 126 (2010) 406-413.

[9] C.H. Kim, B.S. Choi, K. Sapkota, S. Kim, H.J. Lee, J.C. Yoo, S.J. Kim, Process Biochem. 46 (2011) 1545-1553.

[10] W.L. Chandler, Critical Rev. Hematol. Oncol. 24 (1996) 27-45.

[11] K.P. Pratt, H.C.F. CoTe, D.W. Chung, R.E. Stenkamp, E.W. Davie, Proc. Natl. Acad. Sci. U.S.A. 94 (1997) 7176-7181.

[12] R. Agrebi, A. Haddar, N. Hmidet, K. Jellouli, L. Manni, M. Nasri, Process Biochem 44 (2009) 1252-1259.

[13] J.R. Simkhada, P. Mander, S.S. Cho, J.C. Yoo, Process Biochem. 45 (2010) 88-93.

[14] W.K. Kim, K.H. Choi, Y.T. Kim, H.H. Park, J.Y. Choi, Y.S. Lee, H.I. Oh, I.B. Kwon, S.Y. Lee, Appl. Environ. Microbiol. 62 (1996) 2482-2488.

[15] H.S. Choi, P.H. Shin, Mycologia 4 (1998) 674-679.

[16] Y. Peng, X.J. Yang, Y.Z. Zhang, Appl. Microbiol. Biotechnol. 69 (2005) 126-132.

[17] L.H.M. Silva, W. Loh, Quim. Nova 29 (2006) 1345-1351.

[18] M.T.H. Cavalcanti, T.S. Porto, B.B. Neto, J.L. Lima-Filho, A.L.F. Porto, A. PessoaJunior, J. Chromatogr. B 833 (2006) 135-140.

[19] Y. Liu, Y.L. Yu, M.Z. Chen, X. Xiao, Can. J. Chem. Eng. Technol. 2 (2011) 1-7.

[20] A.J. Castellani, Trop. Med. Hyg. 70 (1967) 181-184.

[21] A.L.F. Porto, G.M. Campos-Takaki, J.L. Lima-Filho, Appl. Biochem. Biotechnol. 60 (1996) 115-121.

[22] T.G. Pridham, P. Aderson, C. Foley, L.A. Lindenfelser, C.W. Hesseltine, R.G.A Benedict, Antibiot. Man. (1957) 947-953.

[23] R. Hatti-Kaul. Methods in Biotechnology. Ed. 11. Suécia, 2000

[24] T.S. Porto, G.M.M. Silva, C.S. Porto, M.T.H. Cavalcanti, B.B. Neto, J.L. Lima-Filho, A. Converti, A.L.F. Porto, A. Pessoa Jr., Chem. Eng. Process. 47 (2008) 716-721.

[25] J.-K. Wang, H.-H. Chiu, C.-S. Hsieh, Fooyin J. Health Sci. 1 (2009) 21-27.

[26] M.M. Bradford, Anal. Biochem. 72 (1976) 248-254.

[27] R.E. Bruns, I.S. Scarminio, B.B. Neto, Statistical design-chemometrics, vol. I, first ed., Elsevier, Amsterdam, 2006.

[28] Statsoft Inc., STATISTICA (Data Analysis Software Systems) Version 8.0, 2008.

[29] J.F. Ferreira, G.S. Padilha, E.B. Tambourgi, Exacta 7 (2009) 49-56.

[30] S. Saravanan, J.R. Rao, B.U. Nair, T.R. Saravanam, Process Biochem. 43 (2008) 905-911.

[31] P. Vats, U.C. Banerjee, Enzyme Microb. Technol. 39 (2006) 596-600.

[32] B.R. Babu, N.K. Rastogi, K.S.M.S. Raghavarao, Chem. Eng. Process. 47 (2008) 83-89.

[33] S. Yang, Z. Huang, Z. Jiang, L. Li, Process Biochem. 43 (2008) 56-61.

[34] S. Ketnawa, S. Rawdkuen, P. Chaiwut, Biochem. Eng. J. 52 (2010) 205-211.

[35] C.S. Silva, E. Bovarotti, M.I. Rodrigues, C.O. Hokka, M. Barboza, Bioprocess Biosyst. Eng. 32 (2009) 625-632.

[36] S. Rawdkuen, P. Pintathong, P. Chaiwut, S. Benjakul, Food Bioprod. Process. 89 (2011) 73-80.

[37] G. Tubio, B. Nerli, G. Picó, J. Chromatogr. B 799 (2004) 293-301.

[38] Z.D.V.L. Mayerhoff, I.C. Roberto, T.T. Franco, Biochem. Eng. J. 18 (2004) 217-223.

[39] S.M. Pancera, L.H.M. Silva, W. Loh, R. Itri, A. Pessoa Jr., D.F.S. Petri, Colloids Surf. B 26 (2002) 291-300.

[40] R.F.F. Araújo, T.S. Porto, D.B.G. Martins, R.F. Dutra, A.L.F. Porto, J.L. Lima-Filho., Fluid Phase Equilib. 301 (2011) 46-50.

[41] M.T.H. Cavalcanti, T.S. Porto, B.B. Neto, J.L. Lima-Filho, A.L.F. Porto, A. Pessoa Jr. J. Chromatogr. B 833 (2006) 135-140.

[42] M.L.C. Neves, T.S. Porto, C.M. Souza-Motta, M.R. Spier, C.R. Soccol, K.A. Moreira, A.L.F. Porto, Fluid Phase Equilib. 318 (2012) 34-39.

[43] N.B. Iannucci, S.A. Camperi, O. Cascone, Sep. Purif. Technol. 64 (2008) 131-134.

[44] T.S. Porto, P.P. Marques, C.S. Porto, K.A. Moreira, J.L. Lima-Filho, A. Converti, A Pessoa, A.L.F. Porto, Appl. Biochem. Biotechnol. 160 (2010) 1057-1064.

[45] J.T. Faria, F.C. Sampaio, A. Converti, F.M.L. Passos, V.P.R. Minim, L.A. Minim, J. Chromatogr. B 877 (2009) 3031-3037.

[46] S.L. Wang, Y.Y. Wu, T.W. Liang, New Biotechnol. 28 (2011) 196-202. 
[47] F. Lu, Z. Lu, X. Bie, Z. Yao, Y. Wang, Y. Lu, Y. Guo, Thromb. Res. 126 (2010) e349-e355.

[48] L.R. Rodrigues, A. Venâncio, J.A. Teixeira, Biotechnol. Lett. 23(2001)1893-1897.

[49] P.A.J. Rosa, I.F. Ferreira, A.M. Azevedo, M.R. Aires-Barros, J. Chromatogr. A 217 (2010) 2296-2305.
[50] P.A. Rosa, A.M. Azevedo, S. Sommerfeld, W. Backer, M.R. Aires-Barros, Biotechnol. Adv. 6 (2011) 559-567.

[51] T.S. Porto, T.I.R. Monteiro, K.A. Moreira, J.L. Lima-Filho, M.P.C. Silva, A.L.F Porto, M.G. Carneiro-da-Cunha, World J. Microbiol. Biotechnol. 21 (2005) 655-659. 